\title{
The Effect of Problem Based Learning Teaching Method on Students' Critical Thinking Skills in Physics Lesson at SMA Negeri 4 Singaraja
}

\author{
Ni Putu Ayu Lisniandila, I Wayan Santyasa, Iwan Suswandi \\ Physics Education Major, Mathematics and Science Faculty \\ Universitas Pendidikan Ganesha \\ Singaraja, Indonesia \\ ayulisniandila@gmail.com
}

\begin{abstract}
The study aims to find the effect of problem based-learning method (PBL) on students' critical thinking skills in a physics course at SMA Negeri 4 Singaraja. The study is a quasi-experiment study with a pretest-posttest nonequivalent control group design. The population of this study was 245 tenth graders majoring in science at SMA 4 Singaraja. The sample of this study was 67 students distributed to two different classes. The data were analyzed by using descriptive analysis and oneway analysis of covariance (ANCOVA). The result of the study shows that there was critical thinking skills gaps between the students using PBL and students using the direct instruction method (DIM). The average score of PBL group had higher average critical thinking skills score (posttest) then the MDI group, in which the scores of PBLM group were in adequate category $(\mathrm{M}=54,84 ; \mathrm{SD}=14,50)$, meanwhile the scores of DIM group were in low category $(M=43,05 ; \mathrm{SD}=14,29)$.
\end{abstract}

Keywords: problem-based learning, critical thinking skills, physics course

\begin{abstract}
Abstrak : Penelitian ini bertujuan mengetahui pengaruh model problem based learning (MPBL) terhadap kemampuan berpikir kritis siswa dalam pembelajaran fisika di SMA Negeri 4 Singaraja. Penelitian ini merupakan penelitian kuasi eksperimen dengan desain pretest-posttest nonequivalent control group design. Populasi penelitian ini adalah siswa kelas X MIPA SMA Negeri 4 Singaraja yang terdiri dari 245 siswa. Pemilihan sampel dalam penelitian ini menggunakan random assignment. Jumlah sampel dalam penelitian ini sebanyak 67 siswa yang terdistribusi dalam dua kelas berbeda. Teknik analisis data yang digunakan adalah analisis deskriptif dan ANAKOVA satu jalur. Hasil penelitian menunjukkan bahwa terdapat perbedaan kemampuan berpikir kritis siswa antara siswa yang berlajar dengan MPBL dan siswa yang belajar dengan MDI. Nilai rata-rata kelompok MPBL memiliki nilai rata-rata kemampuan berpikir kritis (posttest) yang lebih unggul dibanding kelompok MDI yaitu pada kelompok MPBL berada pada kualifikasi cukup $(\mathrm{M}=54,84 ; \mathrm{SD}=14,50)$ sedangkan kelompok MDI pada kualifikasi rendah $(\mathrm{M}=43,05 ; \mathrm{SD}=14,29)$.
\end{abstract}

Kata kunci: model problem based learning, kemampuan berpikir kritis, pembelajaran fisika

\section{INTRODUCTION}

The Physics course is a part of science that is essential for students. The goal of the Physics course within the 2013 Curriculum is to master its concept and principle; the skills to develop the knowledge and the confidence to pursue a higher level of education, in order to develop the science and technology (The Ministry of Education and Culture, 2014). As for the paramount component to increase the conceptual and principle mastery in physics is the critical thinking skills. Consequently, students are expected to have optimal critical thinking skills, in order to fulfill the goal of physics courses.

The previous study was conducted by Susilawati (2017) shows that the critical thinking skills of students at SMP Negeri 2 Mataram are classified as low. It is proven by the average score of the initial critical thinking test from high achieving students in both experiment and control classes are 58,10 and 55,65 , respectively, meanwhile the low achieving students score in both experiment and control classes are 56,73 and 55,65, respectively. A similar study 
was also conducted by Lestari et al. (2016) shows that the critical thinking skills of students at SMPN 2 Bojo is categorized as low due to their average score on the initial critical thinking test does not reach the minimum standard, which is 46,39 on the experiment class and 34,75 on the control class, The result of those studies shows that there is a gap between the expectation and the reality.

The gap was created by the students' low critical thinking skills caused by the teacher-centered teaching methods that still implemented by most teachers. The example of that teachers-centered teaching method is the direct investment method (DIM). According to Noer (in Umar, 2017), students' less optimal critical thinking skills is caused by the teacher's inaccuracies to choose the implemented teaching method and strategy within the classroom.

The means to solve the problem mentioned above comes from an innovative teaching method that allows students to apply their knowledge in solving their daily issues. One of the teaching methods that can make the students become more active during the teaching process is problem-based learning. Noordin (in Susilawati et al., 2017) mentions teaching method using problem-based learning is an innovative teaching strategy in which teachers encourage students to develop their problem-solving skills, creativity, and critical thinking skills.

Therefore, PBL implies to increase students' critical thinking skills. PBL exposes students to the real problem in daily life that requires students to think critically whenever they try to find its solvency. That statement is supported by several results of studies 1) result of the study conducted by Fitritani et al. (2015) shows that PBL strategy gives significant effect on critical thinking skills and positive contribution on the critical thinking improvement, 2) a study conducted by Herayanti and Habibi (2015) shows that the enhancement of college students' critical thinking on static electricity concept who have undergone a lesson with problem-based teaching method assisted with computer simulation is higher than college students who have undergone a conventional teaching.

As the consequence, the researcher got an inspiration to conduct a study, entitled "The Effect of Problem Based Learning Teaching Method on Students' Critical Thinking Skills in Physics Lesson at SMA Negeri 4 Singaraja".

Based on the background of the study mentioned above, the problem of this study is "Are there any differences in the critical thinking skills of students who have undergone lessons using problem-based learning and those who have undergone a lessons using Direct Instruction?".

According to that problem of the study, theoretically, it can be explained as follows.

In accordance with constructivism, teaching is characterized as experimentation, question, investigation, hypothesis, and methods created by students themselves. One of the teaching methods that follows constructivism is problem-based learning. Santyasa (2017) states that problem based learning (PBL) is a teaching method that uses the real and ill-structured problem as the basis of the teaching, thus, students can use their skills to analyze the given problems, acquire new information, and use their initial knowledge to solve the problem.

The advantages of using PBL according to Sanjaya (2007) are: 1) it is a good technique to master the teaching materials, 2) it challenges students, yet, it also provides satisfaction whenever students find a new knowledge, 3) it improves students learning activities, 4) it helps students to use their knowledge in understanding their real-life problem, 5) it helps students to develop their new knowledge and become responsible during the learning process. Moreover, it also encourages students to do self-evaluation for their result and process, 6) it shows students that every lesson basically teaches them a way to think that they should understand, not only knowledge they get from their teachers and books, 7) students considered it as a more fun teaching methods than the others, 8) it can improve students' skills in order to increase their achievement and develop their skill to adapt with the new knowledge, 9) it gives students the opportunities to implement their knowledge in the real world, and 10) it develops students interest to continuously learn even after they finish their formal education.

Critical thinking is the ability to logically and reflectively think in order to decide what to do and what to believe. Someone who thinks logically involves efforts to carefully analyze arguments, find a valid truth, and reach a conclusion (Ennis, 1993). The dimensions and indicators of critical thinking, stated by Ennis (in Costa, 1991), are presented in Table 1.

\section{METHODOLOGY OF THE STUDY}

The study is a quasi-experiment with a oneway non-equivalent pretest-posttest control group design. The design of the study is depicted in Graphic 1. 


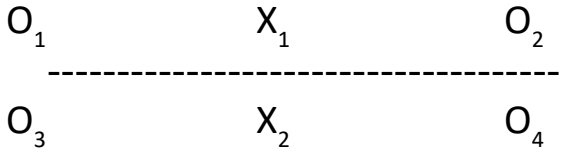

Graphic 1. The design of the study

(Source: Santyasa, 2018)

Description:

$\mathrm{O}_{1}$ and $\mathrm{O}_{3}=$ The initial observation on students critical thinking skills

$\mathrm{O}_{2}$ and $\mathrm{O}_{4}=$ The final observation on students critical thinking skills

$\mathrm{X}_{1} \quad=$ Treatment using problem-based learning

$\mathrm{X}_{2} \quad=$ Treatment using problem-based instruction

This study was conducted from 28 March 2018 to 9 May 2018 at SMA Negeri 4 Singaraja. The population for this study was 245 ten graders majoring in science at SMA Negeri 4 Singaraja in the 2017/2018 academic year. The sample in this study was chosen by random assignment. The total sample was 67 students who are $27,3 \%$ of the total population. The composition of the sample in this study was presented in Table 2, based on the treatment given to them.

There are three variables in this study, free variable, bound variable, and covariate variable. The free variable tested in this study is problem-based learning teaching method and the controlled free variable is the direct instruction method. Meanwhile, the bound variable in this study is students' critical thinking skills. The last, the covariate variable that is being controlled in this study is students' initial critical thinking skills. The relation between those variables is presented in Graphics 2.

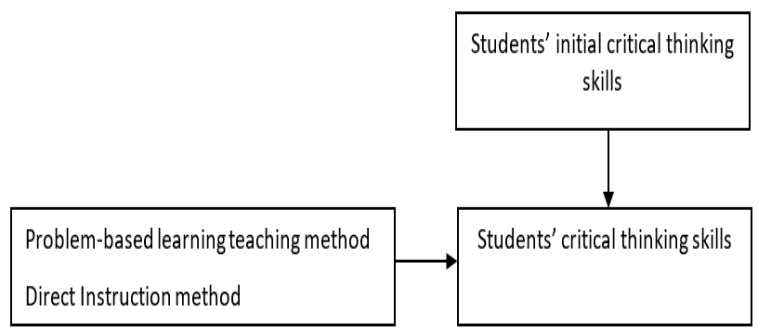

Graphic 2. The Relation between Variables.

The research instrument used to collect data for this study was a critical thinking test. The technique used to collect the data were pretest and posttest. The pretest was conducted to collect data about students' initial critical thinking skills before they received any treatment. The posttest was conducted to collect data about students' critical thinking skills after they received treatments. Before the instrument

Table 1. Dimensions and Indicators of Critical Thinking

\begin{tabular}{|c|c|c|}
\hline No. & Critical thinking dimensions & Indicators \\
\hline 1. & Formulating Problems & $\begin{array}{l}\text { The problems are formulated in accordance with the narrative of the } \\
\text { problems. } \\
\text { Formulating the problems in the form of questions that lead to the answers. }\end{array}$ \\
\hline 2. & Giving arguments & $\begin{array}{l}\text { Arguments are made with relevant reasons. } \\
\text { Showing differences and similarities. }\end{array}$ \\
\hline 3. & Drawing Deductive reasoning & $\begin{array}{l}\text { Logically draw deductive reasoning. } \\
\text { Interpreting the questions. }\end{array}$ \\
\hline 4. & Drawing Inductive reasoning & $\begin{array}{l}\text { Do a complete investigation/data collection. } \\
\text { Draw a generalization from data, make a table and graphics. }\end{array}$ \\
\hline 5. & Evaluating & $\begin{array}{l}\text { Give solutions or suggestions based on the problems. } \\
\text { Give alternatives based on the theory. }\end{array}$ \\
\hline 6. & Deciding and Implementing & $\begin{array}{l}\text { Choose the existing possible alternatives. } \\
\text { Decide the existing possible solution that will be implemented based on } \\
\text { the theory. }\end{array}$ \\
\hline
\end{tabular}

(Adopted from Ennis in, Costa 1991)

Table 2. The Sample of study in each treatment

\begin{tabular}{llll}
\hline No. & Class & Treatment & Total Students \\
\hline 1. & X Science 3 & Problem-based learning & 35 students \\
\hline 2. & X Science 6 & Direct Instruction & 32 students \\
\hline Total Sample & & 67 Students \\
\hline
\end{tabular}


was tried out first before it was used to collect the data for the study. The try out covered test content validity, items difficulty index, items discrimination index, items internal consistency, and test reliability.

Based on the analysis from the tried out critical thinking test, there were 15 accepted items out of 18 essay items. Considering the content validity of the test, materials coverage, and the time allocation provided by the school, 90 minutes, there were 15 items in the critical thinking skills test that could be used with the score for each item ranging from 0 to 4 .

The analysis data technique in this study is descriptive analysis and one-way ANCOVA. The descriptive analysis was used to describe the percentage of average scores or the Mean (M) and the standard deviation (SD). While the analysis of covariance (ANCOVA) was used to test the hypothesis. ANCOVA is a parametric statistic, therefore, it needs an assumption test in the form of normality test using Komogorov Test and ShapiroWilk Test statistical analysis, whereas test of homogeneity was conducted using Levene's Test of Equality of Error Variance, and linearity test were conducted using statistical analysis of linearity. All of those tests were done in SPSS 2.0 application for Windows.

\section{Result of the Study}

The scores average and standard deviation of students' initial critical thinking skills from both groups with problem-based learning method and direct instruction method were presented in Table 3.

Based on the data in Table 3, the average score of students' initial critical thinking skills (pretest) on the PBL group was 18,13 that was classified as very low with 5,66 standard deviation. On the other hand, the average scores of students' in the DIM group is 18,48 categorized as very low with 6,19 standard deviation. To conclude, the average scores of DIM students' initial critical thinking were relatively higher than the PBL group.

The average scores and standard deviation. In addition, students' learning achievements for each group after they received PBL and DIM treatment are presented in Table 4.

According to the data in Table 4, the average scores of PBL students' critical thinking skills after they received treatment (posttest) were 54,84 categorized as high with 14,50 standard deviation. On the contrary, the average scores of DIM students' critical thinking skills after they received treatment (posttest) is 43,05 categorized as adequate with 14,29 standard deviation. The average scores of students' critical thinking skills on each dimension are shown in Table 5.

Based on Table 5, the average score of the PBL group on each dimension of critical thinking skills relatively higher than the average scores of the DIM group. The highest average score of the PBL group was 59,75 in the dimension of giving arguments, as

Table 3. The average scores of students' initial critical thinking skills

\begin{tabular}{lllll}
\hline Class & Teaching Method & M & SD & Qualification \\
\hline 10 Science 6 & PBL & 18,13 & 5,6 & Very low \\
\hline 10 Science 3 & DIM & 18,48 & 6,19 & Very low \\
\hline
\end{tabular}

Table 4. The Average Scores (with 100 scale) and Standard deviation of Students' Critical Thinking Skills

\begin{tabular}{lllll}
\hline Class & Teaching Method & M & SD & Qualification \\
\hline 10 Science 6 & PBL & 54,84 & 14,50 & High \\
\hline 10 Science 3 & DIM & 43,05 & 14,29 & Adequate \\
\hline
\end{tabular}

Table 5 The Average Scores of Students Critical Thinking Skills on Each Dimension

\begin{tabular}{|c|c|c|c|c|c|c|c|}
\hline \multirow{2}{*}{ Group } & \multicolumn{6}{|c|}{ Dimensions of Average Scores Critical Thinking Skill } & \multirow{2}{*}{ Total Average } \\
\hline & $\mathbf{A}$ & B & $\mathbf{C}$ & $\mathbf{D}$ & $\mathbf{E}$ & $\mathbf{F}$ & \\
\hline PBL & 59,0 & 59,75 & 43,00 & 56,25 & 51,25 & 39,50 & 39,33 \\
\hline DIM & 47,50 & 49,75 & 22,25 & 50,25 & 36,50 & 29,75 & 51,46 \\
\hline
\end{tabular}

Description: $\mathrm{A}=$ formulating problems. $\mathrm{B}=$ giving arguments. $\mathrm{C}=$ drawing deductive reasoning. $\mathrm{D}=$ drawing inductive reasoning. $\mathrm{E}=$ evaluating. $\mathrm{F}=$ deciding and implementing. 
the highest average score of the DIM group was in the dimension of drawing inductive reasoning, 50,25.

Descriptively, the average scores of students' critical thinking skills who had undergone lessons using problem-based learning method (PBL) was higher than the average scores of students' critical thinking skill who had undergone lessons using direct instruction method (DIM). Therefore, the students who had undergone lessons using problem based learning method (PBL) were better than those who had undergone lessons using the direct instruction method (DIM).

The comparison between students who use problem-based learning method (PBL) and direct instruction method (DIM) can be seen in Graphic 3.

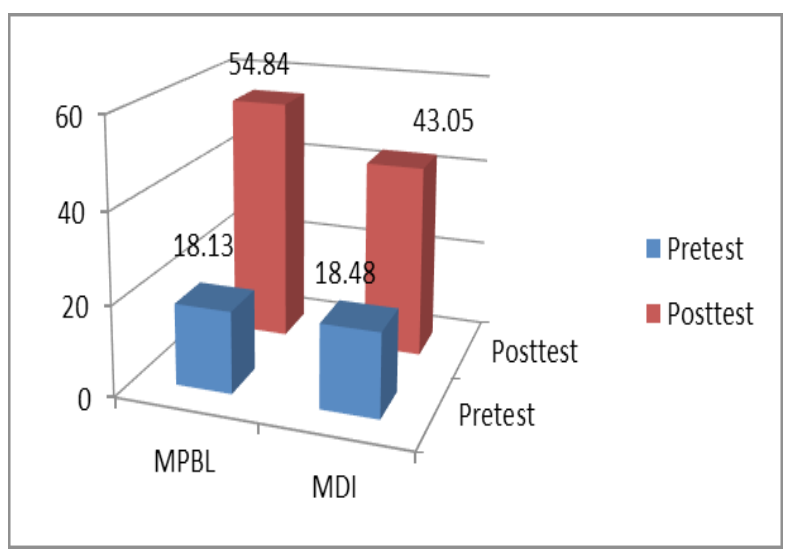

Figure 3. The Comparison of Average Scores from Pretest and Posttest
According to Graphic 3, there were increasing average scores on every unit of students' critical thinking analysis. The students' critical thinking skills acquired by students who had undergone lessons using PBL is relatively better than those undergone lessons using DIM.

Before it was analyzed by one-way ANCOVA, the researchers firstly conducted assumption test, as follows:

First, a normality test was conducted on the data distribution by using Kolmogorov-Smirnov and Shapiro Wilk statistic. The normal data distribution is when the final value of significance is more than 0,05 . Summary of the normality data test result is presented in Table 6.

Based on Table 6 , the value of significance from the data is higher than 0,05 for each group in both Kolmogorov-Smirnov and Saphiro Wilk statistic, thus, it can be concluded that the data collected in this study had a normal distribution.

Second, a test of homogeneity was conducted using Levene's Test of Equality of Error Variance. The data has the same variance if the value of significance resulted is greater than 0.05 . The summary of the test results is presented in Table 7.

Based on table 7, the result of the homogeneity test shows that the values of Levene Statistic has a significant number that is higher than 0,05 . It means that the data variance among study groups is homogeneous.

Third, Linearity Test was conducted by

Table 6. Summary of the Normality Data Test Result

\begin{tabular}{lllllllc}
\hline Model & \multicolumn{5}{c}{ Kolmogorov-Smirnov } & \multicolumn{3}{c}{ Shapiro Wilk } \\
\cline { 2 - 8 } & & Statistic & Df & Sig. & Statistic & Df & Sig \\
\hline \multirow{2}{*}{ Pretest } & PBL & 0,120 & 32 & $0,200^{*}$ & 0,944 & 32 & 0,100 \\
\cline { 2 - 8 } & DIM & 0,109 & 35 & $0,200^{*}$ & 0,947 & 35 & 0,094 \\
\hline \multirow{2}{*}{ Posttest } & PBL & 0,119 & 32 & $0,200^{*}$ & 0,971 & 32 & 0,530 \\
\cline { 2 - 8 } & DIM & 0,130 & 35 & 0,144 & 0,959 & 35 & 0,206 \\
\hline
\end{tabular}

Table. 7. Summary of Homogeneity Test Variance among Group

\begin{tabular}{llllll}
\hline & & Levene Statistic & df1 & df2 & Sig. \\
\hline \multirow{3}{*}{ Pretest } & Based on Mean & 0,161 & 1 & 65,000 & 0,690 \\
\cline { 2 - 6 } & Based on Median & 0,143 & 1 & 65,000 & 0,706 \\
\cline { 2 - 6 } & Based on Median and with adjusted df & 0,143 & 1 & 63,904 & 0,706 \\
\cline { 2 - 6 } & Based on trimmed mean & 0,130 & 1 & 65,000 & 0,720 \\
\hline \multirow{2}{*}{ Posttest } & Based on Mean & 0,082 & 1 & 65,000 & 0,671 \\
\cline { 2 - 6 } & Based on Median & 0,056 & 1 & 65,000 & 0,813 \\
\cline { 2 - 6 } & Based on Median and with adjusted df & 0,056 & 1 & 64,955 & 0,813 \\
\cline { 2 - 6 } & Based on trimmed mean & 0,171 & 65,000 & 0,680 \\
\hline
\end{tabular}


presenting the linear data distribution. The data is linear if the significant value of linearity is less than 0,05 and deviation from linearity is more than 0,05 . The summary of the linearity test is presented in the table 8 and 9.

Based on the Table 8 and 9 on the linearity row, both of them show the significance that is less than 0,05 . It means that the skills of the students' initial critical thinking effects their critical thinking significantly. More than that the significance of deviation of linearity shows the significance that is more than 0,05 . It means that the data distribution to the each groups is linear.

From these normality, homogeneity and linearity tests that was conducted showed that the results of all three assumptions were fulfilled so that it can be continued by testing the hypothesis using one-way ANCOVA analysis. The summary of the test result of the hypothesis using one-way ANCOVA analysis is presented in Table 10.

Based on the ANCOVA result above, it shows the difference on the free variable (learning method) to the bound variable (student's critical thinking skills) that is known from the statistical value $\mathrm{F}$ $=17,982$ with the significant value 0,001 . The significant value is less than 0,05 . The higher the $\mathrm{F}$ value, the higher the error value (bias). It is caused by the influence of external variable and internal variable of the student, hence it uses control variable (initial critical thinking skills of the student) to generalize the result of the study.

From the summary of the ANCOVA test in Table 10, it can be explained as follows: 1) The source of the influence of students' initial critical thinking skills obtained from the pretest on the dependent variable in this study is the critical thinking skills of students, showing that the results of the statistical value $\mathrm{F}=31.992$ with a significance value of 0.001 . This significance rate is more than $0.005(\mathrm{p}<0.05)$. These results indicate that students' critical thinking skills are significantly influenced by the covariate students' initial critical thinking skills. 2) The source of the influence of the method variables used as independent variables on the dependent variable is

Table 8. Result of the PBL Group Linearity Test

\begin{tabular}{|c|c|c|c|c|c|c|c|}
\hline PBL Method & & & Sum of Square & df & Mean Square & $\mathbf{F}$ & Sig. \\
\hline \multirow{5}{*}{$\begin{array}{l}\text { Posttest* } \\
\text { Pretest }\end{array}$} & \multirow{3}{*}{$\begin{array}{l}\text { B e } t w \text { e e } n \\
\text { Groups }\end{array}$} & (Combined) & 1327,68 & 12 & 110,64 & 1,754 & 0,132 \\
\hline & & Linearity & 285,76 & 1 & 285,76 & 5,329 & 0,032 \\
\hline & & $\begin{array}{l}\text { Deviation from } \\
\text { Linearity }\end{array}$ & 1041,92 & 11 & 94,72 & 1,429 & 0,238 \\
\hline & Within Groups & & 1017,03 & 19 & 53,52 & & \\
\hline & Total & & 2344,71 & 31 & & & \\
\hline
\end{tabular}

Table 9. Result of the DIM Group Linearity Test

\begin{tabular}{|c|c|c|c|c|c|c|c|}
\hline DIM Method & & & Sum of Square & df & Mean Square & $\mathbf{F}$ & Sig. \\
\hline \multirow{5}{*}{$\begin{array}{l}\text { Posttest* } \\
\text { Pretest }\end{array}$} & \multirow{3}{*}{$\begin{array}{l}\text { B e t w e e } \mathrm{n} \\
\text { Groups }\end{array}$} & (Combined) & 1916,87 & 12 & 159,73 & 6,017 & 0,000 \\
\hline & & Linearity & 1489,26 & 1 & 1489,269 & 56,093 & 0,000 \\
\hline & & $\begin{array}{l}\text { Deviation from } \\
\text { Linearity }\end{array}$ & 427,603 & 11 & 38,873 & 1,464 & 0,215 \\
\hline & Within Groups & & 584,100 & 22 & 26,550 & & \\
\hline & Total & & 2500,97 & 34 & & & \\
\hline
\end{tabular}

Table 10. Summary of the ANCOVA Hypothesis Testing Result

\begin{tabular}{llllll}
\hline Source & Type III Sum of Square & Df & Mean Square & F & Sig. \\
\hline Corrected Method & $2452,342 a$ & 2 & 1226,171 & 24,290 & 0,000 \\
\hline Intercept & 122,126 & 1 & 1221,126 & 24,190 & 0,000 \\
\hline Pretest & 1614,957 & 1 & 1614,957 & 31,992 & 0,000 \\
\hline Method & 907,728 & 1 & 907,728 & 17,982 & 0,000 \\
\hline Error & 3230,733 & 64 & 50,480 & & \\
\hline Total & 62845,000 & 67 & & & \\
\hline Corrected Total & 563,075 & 66 & & & \\
\hline
\end{tabular}


the critical thinking skills of students obtained from statistical value $\mathrm{F}=17.982$ with a significance value of 0.001 . The significance value is less than 0.05 (p $<0.05)$. Thus a decision can be made, as follows.

$\mathrm{H}_{0}$ : There is no difference in students' critical thinking skills between students who study with problem based learning method and students who learn with direct instruction method. (rejected)

Ha : There is a difference in students' critical thinking skills between students who study with problem based learning method and students who learn with direct instruction method. (accepted)

Therefore, the difference in students' critical thinking skills $(p<0.05)$ is significantly influenced by the learning method used, 3) R squared value obtained based on the results of the analysis is 0.432 indicating that the magnitude of the contribution of the learning method to the differences of students' critical thinking skills between the two groups is $43.5 \%$. Next, a significance analysis of the difference in average scores of students' critical thinking skills through LSD is provided. LSD value can be calculated by finding the estimated average scores of the two groups in advance. Estimated average scores and standard deviations of students' critical thinking skills in each group are presented in Table 11.

The significance of the difference of the average scores of students' critical thinking skills between the PBL and DIM groups was analyzed using the LSD

method. Significance rate is $\alpha=0, \varnothing$, the number of PBL group samples is $n=32$ and DIM is $n=$ 35 , so the total sample size is $\mathrm{N}=67$, the number of methods used is $a=2$, obtained statistics value $t_{\text {tabel }}=t_{(0,025 ; 65)}=3,483$. Summary of the result of the significance testing of the difference of the average scores of students' critical thinking skills between the PBL and MDI groups is presented in Table 12.

Based on Table 12, the difference of the average score of students' critical thinking skills between the PBLand DIM groups is $\Delta \mu=\mu(I)-\mu(J)=7,377$ , with a standard deviation of 1.745 and a significance value of 0.001 . The significance number is less than 0.05 while it is higher than the LSD value, in which based on the calculation the LSD value is 3.483 . These results indicate that there are differences in the average score of critical thinking skills between the PBL and DIM groups. Critical thinking skills achieved by students who learn with problem based learning methods are higher than students who learn with the direct instruction method. It shows that the ability of students to think critically after participating in learning using the problem based learning (PBL) method is relatively better than the group of students who take learning using the direct instruction method (DIM).

\section{DISCUSSION}

The discussion in this study presents a discussion of the results of research and testing of hypotheses concerning the discussion of students' critical thinking skills, especially in the Mathematics and Natural Sciences X class at SMA Negeri 4 Singaraja on work-energy and impulse-momentum materials both in the PBL class and in the DIM class.

Based on univariate analysis, the influence of learning methods is obtained statistical value $\mathrm{F}=$ 17.982 with a significance value of 0.001 which is less than the significance level $0.05(\mathrm{p}<0.05)$. This statistical value means that there are differences in students' critical thinking skills between students

Table 11. Estimated Average Score and Deviation Standard of Students' Critical Thinking Skills of PBL and DIM Group

\begin{tabular}{ccccc}
\hline \multirow{2}{*}{ Method } & \multirow{2}{*}{ SD } & \multicolumn{2}{c}{ Interval Konvidensi 95\% } \\
\cline { 4 - 5 } & & & Lowest & Highest \\
\hline PBL & $33,060 \mathrm{a}$ & 1,256 & 30,550 & 35,570 \\
\hline $\mathrm{DIM}$ & $25,688 \mathrm{a}$ & 1,201 & 23,288 & 28,088 \\
\hline
\end{tabular}

Table 12. Significance of the Difference of Average Scores of Students' Critical Thinking Skills between the PBL and DIM Groups

\begin{tabular}{|c|c|c|c|c|}
\hline (I) Method & (J) Method & $\mu(I)-\mu(J)$ & SD & Sig. \\
\hline MPBL & $\mathrm{MDI}$ & $7,372^{*}$ & 1,739 & 0,000 \\
\hline MDI & MPBL & $-7,372^{*}$ & 1,739 & 0,000 \\
\hline
\end{tabular}


who learn with the problem based learning method and the direct instruction method in learning physics in class X SMA Negeri 4 Singaraja in the academic year 2017/2018. The critical thinking skills achieved by students who take lessons in the PBL class are better compared to students who take lessons in the DIM class.

The result of this study is in line with the study that was done by Suprapto et al. (2017) who stated that problem-based learning method (PBL) has a significant influence on high-level thinking skills that critical thinking is one of them. PBL can increase the students' critical thinking skills because this method is able to make the students become more contributive in the learning process so that the students can be able to think critically (Apriyani, 2017). More than that, the facts that were produced in this study is supported by Laksminidewi (2016) by saying that there are differences between those who study in PBL and those who study in DIM one. The findings of this study indicate that students in the PBL method group have better critical thinking skills than students who learn using the DIM.

Problem based learning method is studentcentered learning and uses real-world problems as a vehicle for developing students' abilities, especially students' critical thinking abilities. Noordin (in Susilawati et al., 2017) stated that the problem based learning method is an innovative teaching strategy in which the teacher encourages students to develop skills in problem solving, creativity, and critical thinking skills.

Learning that applies the direct instruction method (DIM) is different from the problem based learning (PBL) method. In the application of DIM, students tend to be passive, students only listen to the explanation from the teacher. In the DIM the teacher gives the problem and the teacher himself explains the steps to solve the problem. Students only receive information and explanations delivered by the teacher so there is no thinking process for the students. If confronted with a problem, the teacher explains the details of the problem, starting from what is known from the problem, what is asked from the problem, and what is the solution to the problem. Students do not develop their critical thinking skills when getting a problem. This condition will not form students' critical thinking skills optimally.

Although the problem based learning method is more able to improve students' critical thinking skills compared to the direct teaching method, but there are several things that oppose the development through the PBL and DIM which have not been able to reach the critical thinking skills of students in the very high category $(85 \%-100 \%)$. Some of the causes are as follows.

First, students are accustomed to the conventional methods such as direct instruction model which tends to make students passive and teachers who actively provide information, so the students are still not accustomed to applying problem based learning method.

Second, students need a long time to adapt to the problem based learning method, especially when they work on worksheets that must be done according to the stages of problem solving and often students experience obstacles in determining the experiments to be carried out to solve problems, even though mostly some students already have an idea how to solve the given problem.

Third, students are not accustomed to solving problems presented in worksheets, because in previous learning students more often work on problems that are alchemical, where all the variables that are known and asked are available and lead the students to find answers to these problems.

Fourth, students' initial knowledge is different so that there is a gap between students who have good academic skills and students who have less academic skills during the learning process. Each student has the potential to develop their own understanding of the concept but requires different time in the process of understanding. Students who have good academic abilities will more quickly build the understanding of the concept compared to the students who have low academic skills.

Fifth, students are not yet familiar with the form of tests used. In this study the test used was a critical thinking test in the form of essays with a total of 15 items. Students are required to be critical in answering these questions so as to make students burdened in working on the problems.

The implication of the findings of this study is that physics learning in schools must always be about problem solving and applying the problem based learning method. The problem based learning method creates a conducive atmosphere for learning. This is because students are more contributive and more persistent in the tasks given. Students will also be more critical in solving the problems which will certainly affect students' critical thinking skills. This implies that the problem based learning method is more suitable for physics learning in the classroom than the direct instruction method. 


\section{CONCLUSIONS AND SUGGESTIONS}

There is a difference of the ability to think critically between students who learn with problem based learning method and students who learn with direct instruction method in learning physics in class X SMA Negeri 4 Singaraja.

From this study result, the teachers are expected to be able to apply innovative teaching method that one of which is by applying the Problem Based Learning method to be able to improve students' critical thinking skills and the students are expected to maximize their time to study while they are in school.

\section{REFERENCES}

Costa, A. L. 1991. Developing Minds: A Resource Book for Teaching Thinking. Alexandria: Association for supervision and curriculum development.

Ennis, R. H. 1993. Critical thinking assessment. Theory into practice.32(3). [Artikel Online]. Tersedia pada http://www.tandfonline.com /doi/abs/10.1080/ 00405849309543594 . Diakses 19 April 2017.

Fitriyani, R., Corebima, A. D., \& Ibrohim. 2015. Pengaruh strategi pembelajaran problem based learning dan inkuiri terbimbing terhadap keterampilan metakognitif, berpikir kritis, dan hasil belajar kognitif siswa sma. Jurnal Pendidikan Sains, 3(4), 186-200. Tersedia pada http://journal. um.ac.id/ index.php/jps/. Diakses 1 Juli 2017.

Herayanti, L., \& Habibi. 2015. Model pembelajaran berbasis masalah berbantuan simulasi komputer untuk meningkatkan keterampilan berpikir kritis calon guru fisika. Jurnal Pendidikan Fisika dan Teknologi, 1(1), 61-66. Tersedia pada http:// jurnalfkip.unram.ac.id/index.php/JPFT/article/ view/236/232. Diakses 1 Oktober 2017.

Kemendikbud. 2014. Lampiran peraturan menteri pendidikan dan kebudayaan RI Nomor 59 Tahun 2014 tentang Kurikulum 2013 Sekolah Menengah Atas/Madrasah Aliyah. Jakarta: Kementerian Pendidikan dan Kebudayaan.

Lestari, N., Edi, S. S., \& Hartono. 2016. Keefektifan pembelajaran problem based learning berbantuan pohon masalah dalam meningkatkan kemampuan berpikir kritis siswa smp. Unnes Physics Education Journal, 5(1), 56-62. Tersedia pada http://journal. unnes.ac/id/sju/index.php/upej. Diakses 1 Juli 2017.

Putri, S. D., \& Djamas, D. 2017. Pengembangan perangkat pembelajaran fisika berbasis keterampilan berpikir kritis dalam problem based learning. Jurnal Ilmiah Pendidikan Fisika Al-BiRuNi, 06(1), 125-135. Tersedia pada http:// http:// ejournal.radenintan.ac.id/index.php/al-biruni/ article/view/648/pdf. Diakses 7 Desember 2017.

Sanjaya, W. 2007. Strategi pembelajaran berorientasi standar proses pendidikan. Jakarta: Kencana Prenada Media Group.

Santyasa. I. W. 2017. Pembelajaran inovatif. Singaraja: Universitas Pendidikan Ganesha.

Santyasa. I. W. 2018. Metodelogi penelitian pendidikan. Singaraja: Undiksha

Suprapto, E., Fahrizal, Priyono, \& Basri. 2017. The application of problem-based learning strategy to increase high order thinking skill of senior vocational school student . International Education Studies, 10(6), 123-129. Tersedia pada http://doi.org./10.5539/ies.v.10n6p123. Diakses 1 Juli 2017.

Susilawati, Jamaluddin, \& Bachtiar, I. 2017. Pengaruh model pembelajaran berbasis masalah (PBM) berbantuan multimedia terhadap kemampuan berpikir kritis peserta didik kelas vii smp negeri 2 mataram ditinjau dari kemampuan akademik. J. Pijar MIPA, 12(2), 64-70. Tersedia pada http:// jurnalfkip.unram.ac.id/index.php/JPM/article/ view/343/332. Diakses 7 Desember 2017.

Trianto. 2007. Model-model pembelajaran inovatif berorientasi konstruktivistik. Jakarta: Prestasi Pustaka.

Umar, W. 2017. Constructing means ends analysis instruction to improve students' critical thinking ability and mathematical habits of mind disposition. International Journal of Education and Research, 5(2), 261-272. Tersedia pada http:// www.ijern.com/journal/2017/February-201/22. pdf. Diakses 12 Maret 2017. 